\title{
Evaluation of the anticonvulsant effect of nimodipine and amlodipine in mice using maximal electroshock test
}

\author{
Pramod D. Shankpal, Priyanka M. Tawte*
}

\begin{abstract}
Department of Pharmacology, Topiwala National Medical College and BYL Nair Charitable Hospital, Mumbai, Maharashtra, India
\end{abstract}

Received: 21 January 2021

Accepted: 02 March 2021

*Correspondence:

Dr. Priyanka M. Tawte,

Email: dr.priyankatawte@gmail.com

Copyright: (c) the author(s), publisher and licensee Medip Academy. This is an open-access article distributed under the terms of the Creative Commons Attribution Non-Commercial License, which permits unrestricted non-commercial use, distribution, and reproduction in any medium, provided the original work is properly cited.

\begin{abstract}
Background: Initial stage of seizure is due to high frequency burst of action potential, caused by long lasting depolarization of the neuronal membrane because of large influx of calcium $(\mathrm{Ca})$ ions into cells. As there is role of calcium channels in the initiation of seizure potential, there may be role of calcium channel antagonists in treatment of epilepsy. Therefore, we assessed the anticonvulsant effect of nimodipine and amlodipine in mice and compared it with phenytoin and sodium valproate.

Methods: A total 42 mice were randomly divided into 7 groups with 6 mice each. Group 1 vehicle (1\% CMC), group 2- phenytoin (25 mg/kg) and group 3- sodium valproate (100 mg/kg) p.o. group 4 and 5- nimodipine (4 mg/kg and 8 $\mathrm{mg} / \mathrm{kg}$ ), group 6 and 7- amlodipine $(0.7 \mathrm{mg} / \mathrm{kg}$ and $1.3 \mathrm{mg} / \mathrm{kg})$ p.o. in $1 \%$ CMC. All animals were tested for convulsions with current strength $50 \mathrm{~mA}$ for 0.2 seconds, delivered by ear electrodes of electroconvulsiometer. Parameters assessed were presence or absence of convulsions, onset of (latency to) THLE and duration of THLE in seconds, 24 hours mortality.

Results: The difference in percentage of mice being protected from electro convulsions was found to be statistically significant in group 5 (nimodipine $8 \mathrm{mg} / \mathrm{kg}$ ), group 7 (amlodipine $1.3 \mathrm{mg} / \mathrm{kg}$ ) as compared to group 1(vehicle control) $(\mathrm{p}=0.0152)$. Onset of (latency to) THLE and duration of THLE, expressed as mean (in seconds) \pm standard deviation (SD) and analysed using Kruskal-Wallis non-parametric test showed significant difference in latency to THLE among the groups tested ( $\mathrm{p}$ value $<0.01$ ) and in duration of THLE among the groups tested ( $\mathrm{p}$ value $<0.01$ ), while post- hoc Dunn's test showed a statistically significant difference between latency to and duration of THLE in the nimodipine 8 $\mathrm{mg} / \mathrm{kg}$ and amlodipine $1.3 \mathrm{mg} / \mathrm{kg}$ groups as compared to vehicle control group $(\mathrm{p}<0.01)$. No mortality seen within 24 hours of testing in any group.

Conclusions: Nimodipine $8 \mathrm{mg} / \mathrm{kg}$ and amlodipine $1.3 \mathrm{mg} / \mathrm{kg}$ showed significant anticonvulsant activity (absence of tonic hind limb extension), delayed onset of seizures, reduced duration of seizures comparable to positive control (phenytoin and sodium valproate) and more effective than vehicle control.
\end{abstract}

Keywords: Calcium channel antagonists, Dihydropyridine, Epilepsy, Seizure

\section{INTRODUCTION}

A seizure is a paroxysmal event due to abnormal excessive or synchronous neuronal activity in the brain. Epilepsy describes a condition in which a person has recurrent seizures due to a chronic, underlying process. According to conceptual definition of epilepsy "epileptic seizure is a transient occurrence of signs and/or symptoms due to abnormal excessive or synchronous neuronal activity in the brain". ${ }^{1}$ The definition of epilepsy requires the occurrence of at least one epileptic seizure. ${ }^{1}$ Incidence of epilepsy is $0.3-0.5 \%$, and the prevalence is $5-30$ persons per $1000 .^{2}$ In India the incidence of epilepsy is around 0.20.6 per 1,000 population per year as per the recent studies done in India. ${ }^{3}$ 
The initial stage of seizure is due to high frequency burst of action potential, which is caused by long lasting depolarisation of the neuronal membrane because of large influx of calcium $(\mathrm{Ca})$ ions into cells. ${ }^{2}$ The therapy for epilepsy is symptomatic as the available drugs only inhibit seizures, but neither effective prophylaxis nor cure is available as of now. The mechanisms of action of available therapy fall into three major categories: 1) Decrease firing of neurons mediated by promoting the inactivated state of voltage-activated $\mathrm{Na}+$ channels. 2) Enhanced GABA-Amediated synaptic inhibition. 3) Inhibition of voltageactivated $\mathrm{Ca}^{2+}$ channels. ${ }^{3}$

During experimental studies of seizure, it is observed that there is increase in intracellular concentration of calcium and a decrease in extracellular concentration of calcium. The initiation of epileptogenic activity in the neuron is thought to involve the normal phenomenon known as "intrinsic burst firing", which is activated by an inward $\mathrm{Ca}$ current. It may lead to synchronous burst firing of multiple neurons. ${ }^{4}$ Hence compounds that interfere with the flow of $\mathrm{Ca}$ ions may be useful in the treatment of seizures.

The existence of $\mathrm{L}$ type voltage dependent calcium channels has been demonstrated in many regions of the central nervous system (CNS) such as the cortex, hippocampus, cerebellum, spinal cord. The calciumchannel antagonists (CCA's) acts on $\alpha 1$ subunit of L-type of voltage dependent calcium channels (VDCCs) and inhibit the entry of calcium ion $\left(\mathrm{Ca}^{2+}\right)$ into the excitable cells. It is reported that the blockade or modulation of the function of high-voltage VDCCs (types L, N or P/Q) is associated with the control of partial seizures with or without secondary generalization. Among the effects of calcium channel blockers, a reduced release of neurotransmitters may be related to the protective efficacy of some antiepileptic drugs. ${ }^{5}$ Calcium-channel antagonists are classified as benzothiazepines, phenylalkylamines, dihydropyridines and piperazines. Among these dihydropyridines namely Nimodipine is more extensively taken up from the blood into the brain. ${ }^{6}$ Nimodipine, Amlodipine and Nifedipine belongs to the dihydropyridine group which are one of the most commonly prescribed CCAs in India. ${ }^{7}$

Previous studies in rats and mice have shown anticonvulsant activity of dihydropyridines. ${ }^{7-11}$ As there is role of calcium channels in the initiation of seizure potential, there may be a role of calcium channel antagonists (CCAs) in the treatment of epilepsy. Since we found conflicting reports regarding anticonvulsant effect of dihydropyridines, in order to further explore this finding we decided to conduct this study to evaluate the anticonvulsant effect of nimodipine and amlodipine in swiss albino mice in our institutional setup.

\section{Aims and objectives}

To assess the anticonvulsant effect of nimodipine $4 \mathrm{mg} / \mathrm{kg}$, $8 \mathrm{mg} / \mathrm{kg}$ p.o. and amlodipine $0.7 \mathrm{mg} / \mathrm{kg}, 1.3 \mathrm{mg} / \mathrm{kg}$ p.o. in mice using maximal electroshock test and compare it with that of phenytoin and sodium valproate.

\section{METHODS}

All the drugs in pure powder form were obtained from Pharmaceuticals companies. Forty-two (42) male Swiss albino mice were used for the study, which were procured from a registered breeder. Age and weight of the mice ranged from 6 to 8 weeks and between 20-30 grams respectively. Identification was done using cage tag. The mice were housed in polypropylene cages with husk paddy as the bedding and a stainless-steel top grill having facilities for food and drinking water. The animals were housed in air-conditioned rooms and were fed a standard pellet diet, allowed to eat ad libitum. Purified water (by Aquaguard) was provided in sterilized plastic bottles with stainless steel sipper tubes, ad libitum.

\section{Study design}

After an initial period of acclimatization of 7 days, screening was done. All the 42 mice were screened 24 hours prior to study to check for presence of convulsions. Only those mice which showed presence of convulsions in the form of tonic hind limb extension (THLE) on current application were included in the study. ${ }^{12}$ All 42 mice showed such convulsions and hence were eligible to be included in the study. 42 mice weighing between 20-30 grams were randomly divided into 7 groups $(6$ mice per group).

Group 1 was administered $0.2-0.3 \mathrm{ml}$ of the vehicle p.o. (1\% CMC), group 2 was administered phenytoin (25 $\mathrm{mg} / \mathrm{kg}$ p.o.) and group 3 was administered sodium valproate $(100 \mathrm{mg} / \mathrm{kg}$ p.o. $)$ which were positive controls. ${ }^{7}$ Group 4 was administered nimodipine ( $4 \mathrm{mg} / \mathrm{kg}$ p.o.) and group 5 was administered nimodipine ( $8 \mathrm{mg} / \mathrm{kg} \mathrm{p}$.o.) in $1 \%$ CMC. Group 6 was administered amlodipine $(0.7 \mathrm{mg} / \mathrm{kg}$ p.o.) and group 7 was administered amlodipine $(1.3 \mathrm{mg} / \mathrm{kg}$ p.o.) in $1 \% \mathrm{CMC}$.

All the groups received their respective drugs once orally. The mice were subjected to MES test one hour after the dose was administered

\section{Maximal electroshock test}

One hour after the dose administration, all the animals within each group were tested for convulsions with the current strength $50 \mathrm{~mA}$ for 0.2 seconds, delivered by ear electrodes. ${ }^{13,14}$ The experiment was conducted on a wooden table in order to clearly observe the reactions in the mice. The ears were cleaned with spirit to remove any oil film due to sebaceous gland secretions and then with saline for proper electric contact. On application of the current, the mice underwent an initial phase of tonic flexion, then a phase of tonic extension followed by a variable clonic phase. ${ }^{15}$ In the test, the mice was observed for convulsions in the form of tonic hind limb extension 
(i.e. the hind limbs of animals outstretched $180^{\circ}$ to the plane of the body axis) for 2 minutes. Presence or absence of convulsions was noted. Mortality within 24 hours in each group was noted. Latency to and duration of tonic hind limb extensions in seconds was noted using a stopwatch.

Parameters assessed were presence or absence of convulsions, onset of THLE (latency to THLE) in seconds, duration of THLE in seconds, 24 hours mortality in any group. Onset of THLE (latency to THLE) in seconds was noted using a stopwatch keeping a cut-off latency time of 20 seconds for the mice that do not show any convulsions. ${ }^{13}$ The duration of THLE for the mice showing no convulsions was taken as zero.

\section{Statistical analysis}

Assessment of MES test: Experimental data for the parameters, presence or absence of convulsions and mortality, expressed as proportions, were analysed using Fisher's exact test of probability. The parameters, onset of (latency to) THLE and duration of THLE, expressed as mean (in seconds) \pm standard deviation (SD), were analysed using Kruskal-Wallis non-parametric test (as the data obtained is not normally distributed), followed by post-hoc Dunn's test for multiple comparisons. A p value of $<0.05$ was considered statistically significant. Statistical analyses were performed using GraphPad InStat 3 software.

\section{RESULTS}

\section{Presence or absence of convulsions}

The data indicating the presence or absence of convulsions is shown in Table 1.

Table 1: Incidence of convulsions in study using maximal electroshock model.

\begin{tabular}{|lllll|}
\hline $\begin{array}{l}\text { Group } \\
\text { no. }\end{array}$ & $\begin{array}{l}\text { Group } \\
\text { description }\end{array}$ & Present & Absent & P value \\
\hline $\mathbf{1}$ & CMC 1\% & 6 & 0 & \\
\hline $\mathbf{2}$ & $\begin{array}{l}\text { Phenytoin } \\
25 \mathrm{mg} / \mathrm{kg}\end{array}$ & 0 & 6 & $0.0022^{*}$ \\
\hline $\mathbf{3}$ & $\begin{array}{l}\text { Sodium } \\
\text { valproate } \\
100 \mathrm{mg} / \mathrm{kg}\end{array}$ & 1 & 5 & $0.0152^{*}$ \\
\hline $\mathbf{4}$ & $\begin{array}{l}\text { Nimodipine } \\
\text { 4 mg/kg }\end{array}$ & 2 & 4 & 0.0606 \\
\hline $\mathbf{5}$ & $\begin{array}{l}\text { Nimodipine } \\
8 \mathrm{mg} / \mathrm{kg}\end{array}$ & 1 & 5 & $0.0152^{*}$ \\
\hline $\mathbf{6}$ & $\begin{array}{l}\text { Amlodipine } \\
0.7 \mathrm{mg} / \mathrm{kg}\end{array}$ & 2 & 4 & 0.0606 \\
\hline $\mathbf{7}$ & $\begin{array}{l}\text { Amlodipine } \\
1.3 \mathrm{mg} / \mathrm{kg}\end{array}$ & 1 & 5 & $0.0152^{*}$ \\
\hline
\end{tabular}

$* \mathrm{p}<0.05$ - statistically significant compared to group 1 by Fisher's exact test.
The difference in percentage of mice being protected from electro convulsions was found to be statistically significant in group 5 (nimodipine $8 \mathrm{mg} / \mathrm{kg}$ ), group 7 (amlodipine 1.3 $\mathrm{mg} / \mathrm{kg}$ ) as compared to group 1 (vehicle control) $(\mathrm{p}=0.0152$ by Fisher's exact test for all comparisons).

The difference between anticonvulsant action of nimodipine $4 \mathrm{mg} / \mathrm{kg}$ (group 4), nimodipine $8 \mathrm{mg} / \mathrm{kg}$ (group 5), amlodipine $0.7 \mathrm{mg} / \mathrm{kg}$ (group 6) and amlodipine 1.3 $\mathrm{mg} / \mathrm{kg}$ (group 7) as compared to positive control (sodium valproate $100 \mathrm{mg} / \mathrm{kg}$ ) was not statistically significant (p value $=1$, Fisher's exact test) (data not shown in table).

The difference between anticonvulsant action of nimodipine $4 \mathrm{mg} / \mathrm{kg}$ (group 4), amlodipine $0.7 \mathrm{mg} / \mathrm{kg}$ (group 6) as compared to positive control (phenytion 25 $\mathrm{mg} / \mathrm{kg}$ ) was not statistically significant ( $\mathrm{p}$ value $=0.4545$, Fisher's Exact test) and the difference between anticonvulsant action of nimodipine $8 \mathrm{mg} / \mathrm{kg}$ (group 5), amlodipine $1.3 \mathrm{mg} / \mathrm{kg}$ (group 7) as compared to positive control (phenytion $25 \mathrm{mg} / \mathrm{kg}$ ) was not statistically significant ( $\mathrm{p}$ value $=1$, Fisher's exact test) (data not shown in table).

\section{Onset of THLE (latency to THLE) in seconds}

Using a cut-off latency time limit of 20 seconds, the latency in mice with no convulsions was taken as 20 seconds. The data showing onset of THLE (latency to THLE) of study are shown in Table 2.

Table 2: Onset of THLE (latency to THLE) using maximal electroshock model.

\begin{tabular}{|c|c|c|c|}
\hline $\begin{array}{l}\text { Group } \\
\text { no. }\end{array}$ & $\begin{array}{l}\text { Group } \\
\text { description }\end{array}$ & $\begin{array}{l}\text { Mean latency to } \\
\text { THLE (in sec) }\end{array}$ & P value \\
\hline 1 & CMC $1 \%$ & $1.89 \pm 0.1$ & \multirow{7}{*}{$0.0005^{\$}$} \\
\hline 2 & $\begin{array}{l}\text { Phenytoin } 25 \\
\mathrm{mg} / \mathrm{kg}\end{array}$ & $20.00 \pm 0.00 * *$ & \\
\hline 3 & $\begin{array}{l}\text { Sodium valproate } \\
100 \mathrm{mg} / \mathrm{kg}\end{array}$ & $17.25 \pm 6.71 *$ & \\
\hline 4 & $\begin{array}{l}\text { Nimodipine } 4 \\
\mathrm{mg} / \mathrm{kg}\end{array}$ & $14.46 \pm 8.57$ & \\
\hline 5 & $\begin{array}{l}\text { Nimodipine } 8 \\
\mathrm{mg} / \mathrm{kg}\end{array}$ & $17.38 \pm 6.39 *$ & \\
\hline 6 & $\begin{array}{l}\text { Amlodipine } 0.7 \\
\mathrm{mg} / \mathrm{kg}\end{array}$ & $14.62 \pm 8.32$ & \\
\hline 7 & $\begin{array}{l}\text { Amlodipine } 1.3 \\
\mathrm{mg} / \mathrm{kg}\end{array}$ & $17.37 \pm 6.42 *$ & \\
\hline \multicolumn{4}{|c|}{$\begin{array}{l}{ }^{\$} \text { p value statistically significant using Kruskal-Wallis test; } \\
* \text { p value }<0.001 \text { - statistically significant as compared to } \\
\text { control (Group } 1 \text { ); *p value }<0.01 \text { - statistically significant as } \\
\text { compared to control (group } 1 \text { ) by post-hoc Dunn's test for } \\
\text { multiple comparisons. }\end{array}$} \\
\hline
\end{tabular}

As shown in Table 2, there was significant difference in the latency to THLE among the groups tested ( $\mathrm{p}$ value $<0.01$, Kruskal-Wallis test). Maximum latency to THLE was seen in the positive control group (phenytoin $25 \mathrm{mg} / \mathrm{kg}$ ) ( $\mathrm{p}<0.001$, post-hoc Dunn's test) when compared with 
vehicle control. On post-hoc Dunn's test, there was a statistically significant difference between the latency to THLE in the nimodipine $8 \mathrm{mg} / \mathrm{kg}$ and amlodipine 1.3 $\mathrm{mg} / \mathrm{kg}$ groups as compared to vehicle control group $(p<0.01)$. The difference between latency to THLE in the nimodipine $8 \mathrm{mg} / \mathrm{kg}$ and amlodipine $1.3 \mathrm{mg} / \mathrm{kg}$ as compared to that of positive control groups (phenytoin 25 $\mathrm{mg} / \mathrm{kg}$ and sodium valproate $100 \mathrm{mg} / \mathrm{kg}$ ) was not significant.

Graphical representation of mean latency to THLE (in seconds) of groups in study is done in Figure 1.

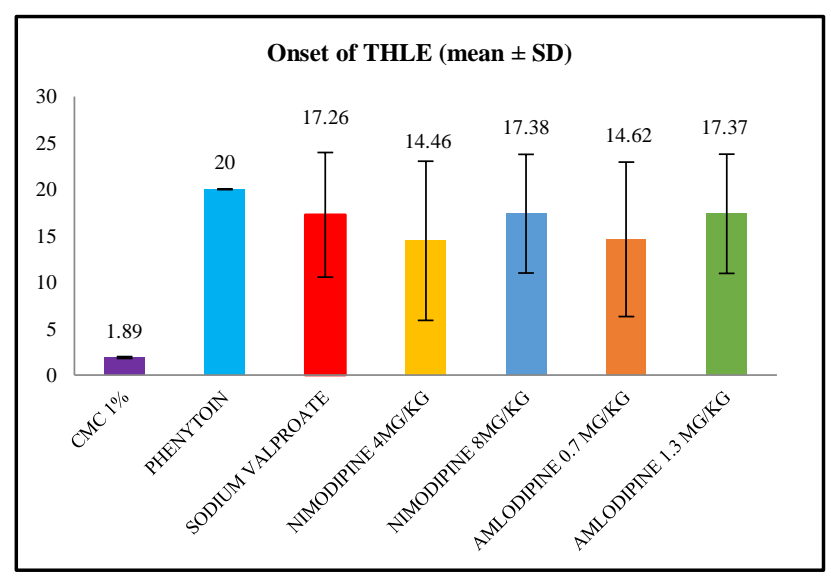

Figure 1: Onset of THLE (latency to THLE) using maximal electroshock model.

\section{Duration of THLE in seconds}

The data showing duration of THLE (seconds) in part 1 are shown in Table 3. Duration of THLE in mice showing no convulsions was taken as 0 . Values are expressed as mean \pm SD.

Table 3: Duration of THLE using MES model.

\begin{tabular}{|c|c|c|c|}
\hline $\begin{array}{l}\text { Group } \\
\text { no. }\end{array}$ & $\begin{array}{l}\text { Group } \\
\text { description }\end{array}$ & $\begin{array}{l}\text { Mean duration of } \\
\text { THLE (in sec) }\end{array}$ & $P$ value \\
\hline 1 & CMC $1 \%$ & $14.35 \pm 1.72$ & \multirow{7}{*}{$0.0004^{\$}$} \\
\hline 2 & $\begin{array}{l}\text { Phenytoin } 25 \\
\mathrm{mg} / \mathrm{kg}\end{array}$ & $0.00 \pm 0.00 * *$ & \\
\hline 3 & $\begin{array}{l}\text { Sodium valproate } \\
100 \mathrm{mg} / \mathrm{kg}\end{array}$ & $1.02 \pm 2.51 *$ & \\
\hline 4 & $\begin{array}{l}\text { Nimodipine } 4 \\
\mathrm{mg} / \mathrm{kg}\end{array}$ & $3.67 \pm 5.67$ & \\
\hline 5 & $\begin{array}{l}\text { Nimodipine } 8 \\
\mathrm{mg} / \mathrm{kg}\end{array}$ & $1.19 \pm 2.91 *$ & \\
\hline 6 & $\begin{array}{l}\text { Amlodipine } 0.7 \\
\mathrm{mg} / \mathrm{kg}\end{array}$ & $3.7 \pm 5.74$ & \\
\hline 7 & $\begin{array}{l}\text { Amlodipine } 1.3 \\
\mathrm{mg} / \mathrm{kg}\end{array}$ & $1.39 \pm 3.40 *$ & \\
\hline
\end{tabular}

$\$ p$ value statistically significant using Kruskal-Wallis test; **p value $<0.001$ - statistically significant as compared to control (group 1); *p value <0.01- statistically significant as compared to control (group 1) by post-hoc Dunn's test for multiple comparisons.
As shown in Table 3, there was significant difference in the duration of THLE among the groups tested ( $\mathrm{p}$ value $<0.01$, Kruskal-Wallis test). On post-hoc Dunn's test, there was a statistically significant difference between the duration of THLE in the nimodipine $8 \mathrm{mg} / \mathrm{kg}$ and amlodipine 1.3 $\mathrm{mg} / \mathrm{kg}$ groups as compared to vehicle control group $(\mathrm{p}<0.01)$.

The difference between duration of THLE in the nimodipine $8 \mathrm{mg} / \mathrm{kg}$ and amlodipine $1.3 \mathrm{mg} / \mathrm{kg}$ as compared to that of positive control groups (phenytoin 25 $\mathrm{mg} / \mathrm{kg}$ and sodium valproate $100 \mathrm{mg} / \mathrm{kg}$ ) was not significant. Thus, the high dose of the test drugs can be said to possess anticonvulsant property.

Graphical representation of duration of THLE (in seconds) of groups in study is done in Figure 2.

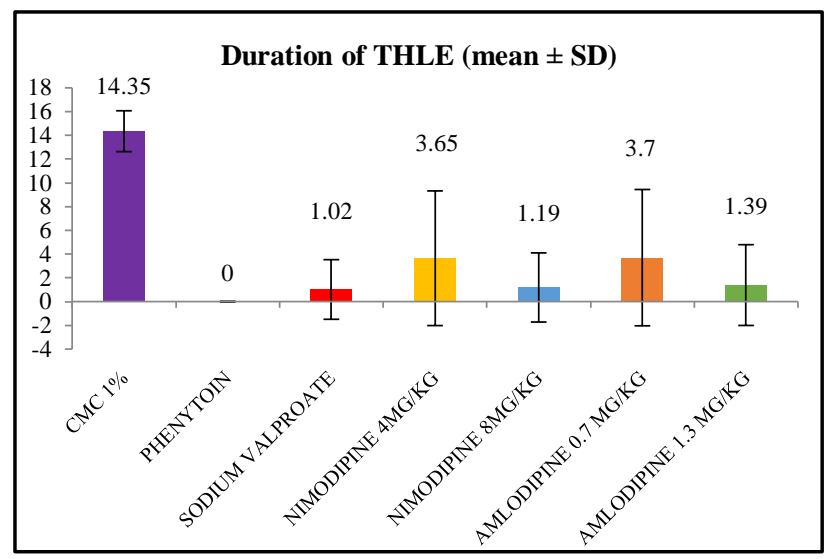

Figure 2: Duration of THLE (in seconds) using maximal electroshock model.

\section{4 hours mortality}

There was no mortality within 24 hours of testing in any group in the study.

\section{DISCUSSION}

In epilepsy calcium plays an important role in generating seizures. $\mathrm{Ca}^{2+}$ is a primary mediator during epileptogenesis and status epilepticus-induced neurotoxicity. It has been shown that epileptic depolarization of neurons is effectively suppressed by $\mathrm{Ca}^{2+}$ channel blocking agents. The $\mathrm{Ca}^{2+}$ channel inhibition by dihydropyridines exhibited protection in experimental models of seizures. Several animal studies have reported that dihydropyridines by virtue of their brain penetrating property potentiate the protective efficacy of some antiepileptic drugs like phenytoin, carbamazepine, valproic acid etc. ${ }^{10,16}$

The therapy for epilepsy is long term, also the available antiepileptic drugs have many side effects along with the higher cost (newer antiepileptic). ${ }^{17}$ Dihydropyridine calcium channel blockers on the other hand have fewer side effect and lower cost. ${ }^{11}$ Nimodipine is a 
dihydropyridine calcium channel blocker which relaxes the cerebrovascular musculature preferentially to the systemic vasculature and is effective in the management of subarachnoid haemorrhage and ischaemic stroke as it is more extensively taken up from the blood into the brain. ${ }^{18,19}$

The present study was planned to evaluate the anticonvulsant action of nimodipine and amlodipine in mice under the parameters of onset of seizures and the duration of seizures using maximal electroshock (MES) test model. Results presented in this study suggest that nimodipine and amlodipine have an anticonvulsant activity of their own with respect of delayed onset of seizures, reduced duration of seizures.

In our study, nimodipine and amlodipine reduced the occurrence of electro convulsions (tonic hind limb extension) as compared to the vehicle control. The number of mice having convulsions in nimodipine $4 \mathrm{mg} / \mathrm{kg}$ was 2 $(\mathrm{n}=6)$ and in $8 \mathrm{mg} / \mathrm{kg}$ was $1(\mathrm{n}=6)$, similarly number of mice having convulsions in amlodipine $0.7 \mathrm{mg} / \mathrm{kg}$ was 2 $(n=6)$ and in $1.3 \mathrm{mg} / \mathrm{kg}$ was $1(n=6)$. This suggests that the anticonvulsant effect could be dose dependent. The number of animals without THLE in nimodipine $8 \mathrm{mg} / \mathrm{kg}$ and amlodipine $1.3 \mathrm{mg} / \mathrm{kg}$ group was significant as compared to vehicle control $(\mathrm{p}=0.0152)$ (Table 1). The difference in protection offered by nimodipine $8 \mathrm{mg} / \mathrm{kg}$ and amlodipine $1.3 \mathrm{mg} / \mathrm{kg}$ was not significant when compared to phenytoin and sodium valproate (positive controls) which means the effect is comparable to that of the positive control.

A drug tested in MES model is said to have anticonvulsant effect if it increases the latency to THLE or decreases the duration of THLE. In our study, we found that latency to THLE in groups nimodipine $8 \mathrm{mg} / \mathrm{kg}$ and amlodipine 1.3 $\mathrm{mg} / \mathrm{kg}$ was more as compared to vehicle control group $(\mathrm{p}<0.01)$. Also, the mean duration of THLE in these groups was significantly lower compared to that of control group $(\mathrm{p}<0.01)$. These findings are in accordance with the findings of the previous parameter (number of animals without THLE- Table 1). Thus, high doses i.e nimodipine $8 \mathrm{mg} / \mathrm{kg}$ and amlodipine $1.3 \mathrm{mg} / \mathrm{kg}$ have some anticonvulsant activity.

Similar findings elaborating anticonvulsant activity of nimodipine and amlodipine were reported in a few earlier studies.

An acute single dose study conducted by Bajracharya et al, demonstrated that amlodipine has an anticonvulsant effect in 30 mice using maximal electroshock test. ${ }^{7}$ Results showed in MES test, amlodipine at $1 \mathrm{mg} / \mathrm{kg}$ did not show anticonvulsant effect whereas in the higher doses of 2 $\mathrm{mg} / \mathrm{kg}$ and $4 \mathrm{mg} / \mathrm{kg}$ there was decreased the duration of tonic hind limb extension. The findings in our study were in agreement to this, as we also found amlodipine in higher dose $(1.3 \mathrm{mg} / \mathrm{kg})$ decreased the duration of tonic hind limb extension.
A study conducted by Hassan et al demonstrated antiepileptic action of amlodipine using maximal electroshock induced seizures in mice in acute phase study. ${ }^{8}$ It was observed that amlodipine (up to $20 \mathrm{mg} / \mathrm{kg}$ ) did not affect electroconvulsive threshold in mice, thus it has no anticonvulsant effect. The finding in our study contradicts these observations as amlodipine was found to be effective as anticonvulsant at higher doses.

A study conducted by Khanna et al demonstrated that in acute studies nifedipine and nimodipine have anticonvulsant effect in mice using MES test and PTZ induced seizure. Results showed that nimodipine at the dose of $5 \mathrm{mg} / \mathrm{kg}$ and $10 \mathrm{mg} / \mathrm{kg}$ and nifedipine $10 \mathrm{mg} / \mathrm{kg}$ exhibited anticonvulsant activity by decreasing the duration of tonic hind limb extension in mice. But in chronic phase only nifedipine showed anticonvulsant activity in PTZ induced seizures. ${ }^{9}$ The results of our study are in accordance to above mentioned study as we have also found that nimodipine at the higher $8 \mathrm{mg} / \mathrm{kg}$ dose exhibited anticonvulsant activity by decreasing the duration of tonic hind limb extension in mice.

Another acute single dose study conducted by Seema et al did not find significant elevation in seizure threshold current in nimodipine $10 \mathrm{mg} / \mathrm{kg}$ whereas nimodipine (20 and $40 \mathrm{mg} / \mathrm{kg}$ ) significantly raised the seizure-threshold current as compared to control group, which suggests that low dose does not possess anticonvulsant effect which contradicts the findings of our study. ${ }^{10} \mathrm{We}$ found nimodipine to be effective as anticonvulsant at $8 \mathrm{mg} / \mathrm{kg}$.

The proposed mechanism of the anticonvulsant activity of calcium channel antagonist is that, the drugs which cross the blood brain barrier (nifedipine, nimodipine) reach at higher concentrations to the brain and effectively suppresses the epileptic depolarization of neurons. ${ }^{6,20}$ Calcium plays an important role in the release of multiple neurotransmitters such as serotonin (5-HT), acetylcholine (Ach), noradrenaline and dopamine from nerve terminals and dendrites in the $\mathrm{CNS}^{21-24}$ Also it effectively suppresses epileptic depolarization of neurons. Hence, it can be hypothesized that a calcium channel antagonist will block the action of these neurotransmitters by preventing their release.

Hypertension disorders may be associated with the development of epilepsy. Systemic hypertension is a cause and risk factor for increased morbidity after aneurysmal subarachnoid haemorrhage (SAH). Patients with hypertension were associated with development of epileptic seizures after $\mathrm{SAH}^{25}$ Also study done by Hesdorffer et al suggest that hypertension and left ventricular hypertrophy without treatment is associated with an increased risk of generalized-onset unprovoked seizure of unknown aetiology among adults. ${ }^{26}$ Hence antihypertensive agents which have an anticonvulsant effect may help in the management of epilepsy along with hypertension. 
Further in vitro studies are required to test for the levels of the drugs in the brain tissues to add more value to the pharmacodynamic evidence obtained from the current study.

The limitation of our study is that we did not evaluate the cumulative effect of chronic administration of nimodipine and amlodipine. Also, we did not measure the concentration of drug of nimodipine and amlodipine in plasma and CNS.

\section{CONCLUSION}

Findings of our study are nimodipine $8 \mathrm{mg} / \mathrm{kg}$ and amlodipine $1.3 \mathrm{mg} / \mathrm{kg}$ showed significant anticonvulsant activity (absence of THLE), delayed onset of seizures, reduced duration of seizures comparable to positive control (phenytoin and sodium valproate) and more effective than vehicle control. However, more detailed and comprehensive studies with larger sample sizes, multiple experimental models and multiple doses are needed to confirm these findings and further paving the way for clinical studies in the future.

Funding: No funding sources

Conflict of interest: None declared

Ethical approval: The study was approved by the Institutional Ethics Committee

\section{REFERENCES}

1. Fisher RS, Acevedo C, Arzimanoglou A, Bogacz A, Cross JH, Elger CE, et al. ILAE official report: a practical clinical definition of epilepsy. Epilepsia. 2014;55(4):475-82.

2. Lowenstein DH. Seizure and epilepsy. In: Braunwald E, Fauci AS, Hauser SL, eds. Harrison's Principles of Internal Medicine. 20th edn. New York: McGrawHill; 2018:3050-3068.

3. Czapinski P, Blaszczyk B, Czuczwar SJ. Mechanisms of action of antiepileptic drugs. Current Top Med Chem. 2005;5(1):3-14.

4. De Lorenzo RJ. A molecular approach to the calcium signal in brain: relationship to synaptic modulation and seizure discharge. Adv Neurol. 1986;44:435-64.

5. Ramirez-San Juan E, Soriano-Ursua MA, EspinosaRaya J, Correa-Basurto J, Trujillo-Ferrara JG, Miranda-Ruvalcaba R, et al. Anticonvulsant effects of bis-1,4-dihydropyridines and the probable role of Ltype calcium channels suggested by docking simulations. Med Chem Res. 2014;23:5149-59

6. Larkin JG, Thompson GG, Scobie G, Forrest G, Drennan JE, Brodie MJ. Dihydropyridine calcium antagonists in mice: blood and brain pharmacokinetics and efficacy against pentylenetetrazol seizures. Epilepsia. 1992;33(4):760-9.

7. Bajracharya SR, Sathyanarayana Rao KN. Antiepileptic effects of amlodipine in mice. J Inst Med. 2016;38(2-3):116-20
8. Mohamed Abdel GH, Ali DM. Antiepileptic action of amlodipine on maximal electroshock induced seizures in mice. Nat $\mathbf{J}$ Physiol Pharm Pharmacol. 2014;4(3):201-7.

9. Khanna N, Bhalla S, Verma V, Sharma KK. Modulatory effects of nifedipine and nimodipine in experimental convulsions. Indian $\mathbf{J}$ Pharmacol. 2000;32(6):347-52.

10. Jain S, Bharal N, Mediratta PK, Sharma KK. Trimetazidine exerts protection against increasing current electroshock seizure test in mice. Seizure. 2010;19(5):300-2.

11. Sreedharan N, Rao PG, Rau NR, Shankar PR. Antihypertensive prescribing preferences in three South Indian Hospitals: cost analysis, physicians perspectives and emerging trends. Int $\mathbf{J}$ Clin Pharmacol Therap. 2011;49(4):277.

12. Siddiqui N, Pandeya SN. Anticonvulsant and hypnotic activities of isodithiobiurets and 1, 2, 4-dithiazolines. Indian J Pharmacol. 1992;24(3):171.

13. Lotarski S, Hain H, Peterson J, Galvin S, Strenkowski $\mathrm{B}$, Donevan $\mathrm{S}$, et al. Anticonvulsant activity of pregabalin in the maximal electroshock-induced seizure assay in $\alpha 2 \delta 1$ (R217A) and $\alpha 2 \delta 2$ (R279A) mouse mutants. Epileps Res. 2014;108(5):833-42.

14. Bhuvaneshwari. Effect of nimodipine and diclofenac in experimentally induced convulsions using INH and electro convulsometer in rats and mice. J Drug Deliv Therap. 2015; 5(1):61-4.

15. Vogel HG. Psychotropic and Neurotropic Activity. In: Drug Discovery and Evaluation: Pharmacological Assays. 3rd edn. Vol 1. Berlin: Springer; 2008:396.

16. Khosla P, Pandhi P. Anticonvulsant effect of nimodipine alone and in combination with diazepam and phenytoin in a mouse model of status epilepticus. Methods Find Exp Clin Pharmacol. 2000;22:731-6.

17. Phatak AM, Hotwani JH, Deshmukh Kiran R, Panchal SS, Naik MS. Cost analysis of long established and newer oral antiepileptic drugs available in The Indian Market. Int J Med Res Health Sci. 2015;4(4):744-8.

18. Tartara A, Galimberti CA, Manniv R, Pariettit L, Zucca C, Baasch $\mathrm{H}$, et al. Differential effects of valproic acid and enzyme-inducing anticonvulsants on nimodipine pharmacokinetics in epileptic patients. $\mathrm{Br}$ J Clin Pharmacol. 1991;32:335-40.

19. Langley MS, Sorkin EM. Nimodipine. Drugs. 1989;37(5):669-99.

20. Uchida S, Yamada S, Nagai K, Deguchi Y, Kimura R. Brain pharmacokinetics and in vivo receptor binding of 1, 4-dihydropyridine calcium channel antagonists. Life Sci. 1997;61(21):2083-90.

21. Middlemiss DN, Spedding M. A functional correlate for the dihydropyridine binding site in rat brain. Nature. 1985;314(6006):94.

22. Nordström ÖI, Braesch-Andersen ST, Bartfai T. Dopamine release is enhanced while acetylcholine release is inhibited by nimodipine (Bay e 9736). Acta Physiol Scand. 1986;126(1):115-9.

23. Kato T, Otsu Y, Furune Y, Yamamoto T. Different effects of L-, N- and T-type calcium channel blockers 
on striatal dopamine release measured by microdialysis in freely moving rats. Neurochem Int. 1992;21:99-107.

24. Pileblad E, Carlsson A. The Ca2+-antagonist nimodipine decreases the Ca2+agonist Bay K 8644 increases catecholamine synthesis in mouse brain. Neuropharmacology. 1987;26:101-5.

25. Rachana PR, Anuradha HV. Anti-hypertensive prescribing patterns and cost analysis for primary hypertension: a retrospective study. J Clin Diagn Res. 2014;8(9):HC19.
26. Ohman J. Hypertension as a risk factor for epilepsy after aneurysmal subarachnoid hemorrhage and surgery. Neurosurgery. 1990;27(4):578-81.

Cite this article as: Shankpal PD, Tawte PM. Evaluation of the anticonvulsant effect of nimodipine and amlodipine in mice using maximal electroshock test. Int J Basic Clin Pharmacol 2021;10:317-23. 